\title{
Re Christ Church, Walshaw
}

Manchester Consistory Court: Tattersall Ch, September 2010 Memorial - heart-shaped - black granite - PCC objections

The daughter of the deceased petitioned for a faculty for the installation on the grave of the deceased of a memorial which did not comply with the diocesan churchyard regulations or the PCC's churchyard policy in that the proposed stone had a 'heart' shape cut in the top of it and was of honed black granite. A number of similar memorials had been placed in a particular area of the churchyard in the past and the PCC's churchyard policy stated that the PCC would object to further such memorials being erected on the basis that the relevant area would otherwise expand indefinitely. The PCC objected to the proposed memorial on the basis that it would set a precedent for future memorials and of pastoral concerns in relation to existing memorials. The DAC did not object to the proposed memorial. The chancellor indicated that the objection to the shape of the memorial would not be determinative of the faculty but that the use of gloss black granite would be inappropriate. He accepted the submission of the PCC that, despite the presence of similar memorials in that area of the churchyard, to authorise the introduction of such a memorial by way of faculty would create a precedent for the introduction of similar memorials in future. He further took account of the fact that to permit this memorial would be likely to cause perplexity and resentment to previous applicants for memorials who had amended their proposals in order to conform to the regulations and policy. The petition was refused and permission was given to the petitioner to apply for approval of a memorial constructed of a different material. [RA]

\section{Obst v Germany; Schüth v Germany}

European Court of Human Rights: September 2010

Employment - dismissal - church doctrine - Article 8

Obst was European Director of Public Relations for the Church of Jesus Christ of Latter-day Saints (LDS). His contract of employment included Church membership as a requirement, a 'good behaviour' clause and the sanction of dismissal on loss of membership. Schüth was a Roman Catholic parish and deanery musician whose terms of employment included the provision that a serious breach of ecclesiastical principles would be good reason for dismissal without notice. Both had extramarital affairs and were dismissed from their respective posts. In June 1985 the Federal Constitutional Court had determined that the Churches could require their employees to maintain the teachings and basic obligations 
applicable to any of their members and much of the argument turned on the margin of appreciation to be afforded in respect of rights under Article 8 of the European Convention on Human Rights (respect for private and family life). The Court concluded that in Obst the domestic courts had conducted a detailed and proper balancing exercise between Obst's rights under Article 8 and the right of the LDS to require a duty of loyalty from its employees and there had been no violation. In Schüth, however, the domestic courts had failed to balance the conflicting rights in a manner consistent with the Convention and there had therefore been a violation of Article 8. The difference between the two cases seems to rest on the relative positions of the applicants: the Court presumably felt that Obst had a far higher profile within the LDS than had Schüth within the Roman Catholic Church. [Frank Cranmer]

A Comment on this case will appear in the next issue of the Journal.

\section{The Druid Network}

Charity Commission for England and Wales: September 2010 Charity - druids - advancement of religion - public benefit

The objects of the Druid Network, an unincorporated association, are 'to provide information on the principles and practice of Druidry for the benefit of all and to inspire and facilitate that practice for those who have committed themselves to this spiritual path'. The Network supports the establishment of local groups and puts interested members of the public in touch with them, supports members in providing public rituals - especially the midwinter and midsummer rituals at Stonehenge - and runs a newsletter and website. It applied to be registered as a charity in accordance with section 3A(1) of the Charities Act 1993. The Commission noted that, insofar as it requires that the advancement of religion be for the public benefit, the definition of religion in charity law differed from that for the purposes of Articles 9 and 14 and Article 1 of the First Protocol of the European Convention on Human Rights. The Commission found that the sincerely held belief in the spirit within and arising from nature as a core element of Druidry represented 'a divine being or entity or spiritual principle' for the purposes of charity law and the Network facilitated and encouraged worship for that supreme being. As to the Campbell and Cosans test of 'cogency, cohesion, seriousness and importance', 6 the Commission noted that the Prison Service 